\title{
Optimizing resource utilization through timely, targeted neurologic care
}

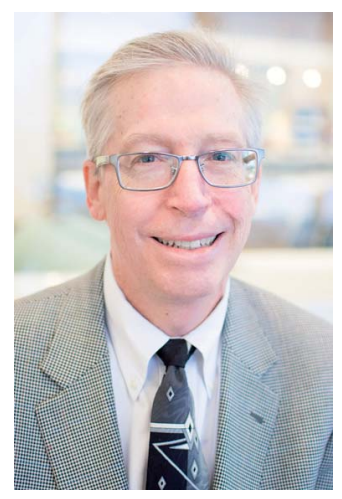

$\mathrm{T}$

wo articles in this issue of Neurology ${ }^{\circledR}$ Clinical Practice (NCP) discuss emergency department (ED) burden and access to outpatient clinics. Patel et al. (p. 480) unplanned hospitalizations. Nourazari et al. (p. 498) demonstrate that poor access to specialty outpatient care is related to increased $\mathrm{ED}$ visits. An accompanying editorial by Adams et al. (p. 472) concludes that "enhancing outpatient neurology access can decrease costs, reduce unnecessary ED visits, increase patient satisfaction, and most importantly, improve health." Black et al. (p. 538) offer practical advice on adding an advanced practice provider to your neurology practice to increase revenue, reduce physician burnout, and improve patient care.

In our Five New Things series, van der Knapp et al. (p. 506) discuss developments in the treatment of leukodystrophies and Deak et al. (p. 523) discuss memory loss. A timely review of Zika virus disease by Smith et al. (p. 515) provides updates on the latest reported neurologic complications, mechanisms of transmission, and testing.

An editorial from Section Editor Luca Bartolini (p. 470) discusses the evolution of our popular Practice Current series. Commentary (p. 530) on the current topic- "When do you stop antiepileptic drugs in patients with genetic generalized epilepsies and in those in focal epilepsies?"- provides a brief overview of the topic and expert commentary from 3 global experts. Go online to participate in our survey or explore the results to date on our interactive map.

As always, we welcome your feedback on this issue and invite suggestions for improving NCP.
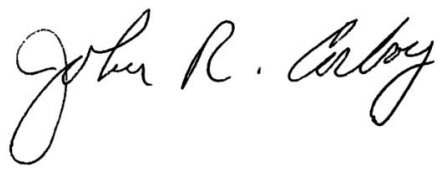

John R. Corboy, MD, FAAN 


\title{
Neurology ${ }^{\circ}$ Clinical Practice
}

\author{
Optimizing resource utilization through timely, targeted neurologic care \\ Neurol Clin Pract 2016;6;467 \\ DOI 10.1212/CPJ.0000000000000327
}

This information is current as of December 12, 2016

\author{
Updated Information \& \\ including high resolution figures, can be found at: \\ Services \\ http://cp.neurology.org/content/6/6/467.full.html \\ Permissions \& Licensing \\ its entirety can be found online at: \\ http://cp.neurology.org/misc/about.xhtml\#permissions \\ Reprints \\ Information about ordering reprints can be found online: \\ http://cp.neurology.org/misc/addir.xhtml\#reprintsus
}

Information about reproducing this article in parts (figures,tables) or in

Neurol Clin Pract is an official journal of the American Academy of Neurology. Published continuously since 2011, it is now a bimonthly with 6 issues per year. Copyright ( 92016 American Academy of Neurology. All rights reserved. Print ISSN: 2163-0402. Online ISSN: 2163-0933.

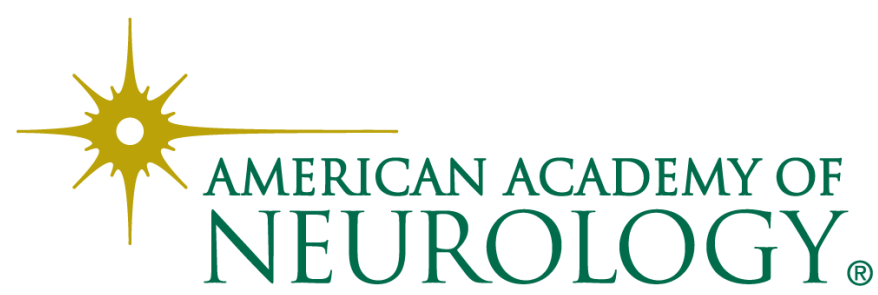

